\title{
On Gendered Technologies and Cyborg Writing
}

\author{
Muhr, Sara Louise; Rehn, Alf
}

Document Version

Accepted author manuscript

Published in:

Gender, Work and Organization

DOI:

10.1111/gwao.12057

Publication date:

2015

\section{License}

Other

Citation for published version (APA):

Muhr, S. L., \& Rehn, A. (2015). On Gendered Technologies and Cyborg Writing. Gender, Work and Organization, 22(2), 129-138. https://doi.org/10.1111/gwao.12057

Link to publication in CBS Research Portal

\section{General rights}

Copyright and moral rights for the publications made accessible in the public portal are retained by the authors and/or other copyright owners and it is a condition of accessing publications that users recognise and abide by the legal requirements associated with these rights.

Take down policy

If you believe that this document breaches copyright please contact us (research.lib@cbs.dk) providing details, and we will remove access to the work immediately and investigate your claim. 


\section{On Gendered Technologies and Cyborg Writing Sara Louise Muhr and Alf Rehn}

Journal article (Post print version)

This is the peer reviewed version of the following article: Muhr S. L., and Rehn A. (2015), On Gendered Technologies and Cyborg Writing, Gender, Work and Organization, 22, 129-138, which has been published in final form at 10.1111/gwao.12057.

This article may be used for non-commercial purposes in accordance with Wiley Terms and

Conditions for Self-Archiving.

Uploaded to Research@CBS: Januar २०16 


\title{
On Gendered Technologies and Cyborg Writing
}

\begin{abstract}
The notion of a specifically feminine writing - écriture féminine - has since Hélène Cixous introduced it in 1975 been discussed as a provocative and potentially disruptive form of representation that breaks with masculine and authoritarian modes thereof. However, we will in this essay discuss how the notion of écriture féminine may itself be at risk of getting trapped within the gender binary its progenitors tried to break free from. We suggest, as a commentary on this, looking at the gendered nature of the research text from the perspective of the technologies with which they are produced, as the writer when writing/publishing - is always already embedded in the technologies of the publishing machine, turning (academic) writing into something akin to cyborg writing. We further suggest that an understanding of the cyborg nature of writing can introduce a parallel mode of inquiry, which holds the potential to enrich écriture féminine and stand as a critique of too simplistic readings of the same.
\end{abstract}

Keywords: cyborg writing, writing technologies, feminine writing, écriture féminine, gender binaries, gendered technologies

\section{Gender (writing) trouble}

Ever since Hélène Cixous (1975) suggested an écriture féminine, the notion of there being a specifically feminine writing with the power to act both as an emancipatory move and as an embodied critique has held sway in the social sciences. Drawing in part on the French post-structuralism out of which it 
emerged (e.g. Chawaf, 1993; Cixous, 1975; 1984; Kristeva, 1980; 1984; Irigaray, 2002), writing on feminine writing has established itself as a micro-field within philosophy/feminist theory, but also as a lively input in a series of other fields, including organization studies (e.g. Höpfl, 2000; 2007; Pullen, 2006; Phillips et al., 2014; Fotaki et al., 2014).

A central argument in the organization studies literature is that the process of writing on organization tends to necessitate conforming to a masculine/patriarchal discourse, which subordinates the feminine (Höpfl, 2000). Academia, in this way, reproduces masculine dominance by what is otherwise referred to as "gender-neutral" procedures (Pullen, 2006). The purpose of an academic écriture féminine is through this connected to disturbing the taken for granted (masculine) neutrality organization studies builds on (Philips et al., 2013) and strives to develop a language which allows for more ethically founded identities, relationships and practices (Fotaki et al., 2014), creating space for "the feminine". This - though obviously a multifaceted and much debated concept - is in the literature mainly related to the body, whereas the masculine is related to the mind (Pullen and Rhodes, 2008). An écriture féminine in organization studies can in this way be associated with writing with the body (see also Fotaki et al. 2014), with emotions (Pullen, 2006) and with being disorderly (Pullen and Rhodes, 2008).

However, despite the fact that critical writings on gender in organization studies (drawing on among others Butler, Cixous and Kristeva) has emphasized a transgressive, multiple, or fluid way of seeing gender, one which is positioned to break with gender essentialism in organization studies (e.g. Ashcraft et al., 2012; Rehn and Borgerson, 2004; Linstead and Pullen, 2006; Muhr, 2011; Muhr and Sullivan, 2013), using écriture féminine as a form of gendered liberating writing is at the same time itself at risk of getting trapped within the gender binary its progenitors tried to break free from. As Pullen (2006, p. 289) notes:

Some poststructuralists-informed female writers in work and organization have adopted a 'confessional' approach to rewriting the self into their research and this is becoming 
successful in redressing the imbalance of women's voices in research, bringing the body back in and reinstating an emotional response. We may, however, wish to question whether this confessional approach names, inscribes and further marginalizes women as other - as abject.

And as Pullen and Rhodes (2008, p. 254) add:

Perhaps any attempt to write as a woman is already doomed to failure, because if we accept that phallogocentrism governs all writing, and regulates women's writing with order, rationality and classification then confronting and opposing such writing could be an acknowledgement of it.

In this way, the very notion of a feminine writing critiquing the masculine and authoritarian modes thereof in organization studies - born out of a tradition coming from Cixous' attempt to challenge the simplistic binaries that so often plague our thinking of gender - often falls back into binaries, weakening the critique it set out to perform in the first place. Attempting to avoid this, recent debates on écriture féminine in organization studies have returned to Cixous' (self-stated) difficult quest of destabilizing the masculine discourse while recognizing that it cannot - and should not - be replaced by its assumed opposite. Phillips et al. (2014, p. 313) argue for examples that écriture féminine in organization studies should be "a writing that challenges masculine orthodoxy by confusing it rather than attempting to replace it", also stressing that écriture féminine is performed by both men and women. This conceptualization of écriture féminine is therefore not a writing tied to women - and the female (or feminine) body - only (Phillips et al., 2014; Fotaki et al., 2014). In this view, écriture féminine is about transgressing, destabilizing and breaking with gender categories rather than building new ones (see also Linstead and Pullen, 2006; Muhr, 2008; Muhr and Sullivan, 2013).

Cixous was herself (see for example Cixous, 1997) aware of the problems involved in completely escaping the constructions of a masculine discourse. Thus, for her, écriture féminine was not necessarily a solution for escaping masculine dominance, but a way to perform a constant destabilization of 
authoritarian notions of masculinity while still recognizing that such a critique was always performed within the gendered structures of society and thus always already gendered (and thereby per definition at risk of falling back into binaries). After all, being a counterpoint - in this case embodying that which its masculine counterpart cannot or dare not include - is in itself a return to a binary. It is this aspect of Cixous' writings and this latter body of organizational theory, problematizing the gendered processes of écriture feminine we draw on and contribute to.

\section{Enter the cyborg}

What prompted us to write this essay, then, is the problem of the reification of the feminine in feminine writing. The debates regarding écriture féminine are, as shown above, often focused on the boundaries of gender, how these can be challenged, and the consequences this may have for a writer. However, by attempting to reify an otherwise extremely abstract and complex concept as "the feminine", one easily slips into essentialist explanations (our reviewers also pointed out how we were doing the same in the first version of this paper - and possibly still are). Even the post-structuralist feminist philosophers themselves, such as e.g. Luce Irigaray, have been accused of essentialism (Fotaki et al., 2014) and as noted above Cixous was herself aware of this risk due to the difficulty of referring to the gender of a writing subject without at least partially returning to binary concepts. When pondering this problem - and while reading the literature on feminine writing in organization studies - it occurred to us that the focus was mainly on the (assumed and interpreted) gender identity of the author (e.g. Höpfl, 2000; 2007; Pullen, 2006) or the gendered discourses that produce a hierarchy for what is defined as proper/clean (i.e. masculine) research and dirty (i.e. feminine) research (e.g. Pullen and Rhodes, 2008). Very little notice has in this been given to the gendering of the technological context within which such writing is produced. Still, even the most experimental écriture féminine is fundamentally affected by being parsed through technologies, and this may/will bring in quite complex and potentially hybrid forms of gendering into what is otherwise seen as the direct agency of the author. The purpose of this paper, 
then, is to pay attention to the gendered technological context around an écriture féminine and discuss ways this can contribute to developing this concept critically by both safeguarding against essentialism and enabling us to discuss the problems - and possibly impossibilities - thereof.

By turning to the technological context within which feminine writing (as all writing) is performed, we do not propose technology as a way out of the binary thinking that plague feminine writing. What we suggest here is that a technological lens provides a parallel mode of inquiry, which serves to enrich our understanding of the difficulties of establishing a feminine writing that can be disruptive and destabilizing, and in this way hopefully serve to enrich the recent critique of too simplistic readings of écriture féminine.

In considering this technological context, we will refer both to the often overlooked gendered history of our writing implements, such as the typewriter, as well as discuss the wider and more abstract technologies of e.g. the peerreviewed journal, as well as the social technologies of textual representation in general. In thinking about the complicated ways in which gender is assigned to an author in the writing process, and to challenge the notion that we can reasonably reduce the act of writing - a mediated, technologically embedded practice - to a gender binary or to a gender identity, we find inspiration in our shared interest in the figure of the cyborg, as this has been used both in science and technology studies (e.g. Clynes and Kline, 1960; Gray, 1995, 2001; Grenville, 2002), feminist theory (Balsamo, 1996; Campbell, 2010; Haraway, 1991; Sharp, 2007), organization studies (Muhr, 2011; Nyberg, 2009; Parker, 1998; 1999) and as a trope in popular culture analysis (e.g. Czarniawska and Gustavsson, 2008; Bowring, 2008). Particularly important for our use of the cyborg metaphor is the way Haraway (1991) uses the metaphor explicitly to challenge gender binaries. In her seminal essay and later work she problematizes the very notion of a gender identity - and its binary foundation - by shifting focus to the fact that we are all constructed by the gendered technologies surrounding us and which our actions are embedded in. Following Haraway, a technological/cyborg 
perspective thus becomes a confrontation of gender binaries in identity construction, as technology per definition will alter such.

What this means in our more limited case of understanding forms of writing is that we understand all writing as being performed by using some kind of technology (whether a pen, a typewriter or a form of advanced information technology). As a consequence we argue that all forms of writing are by necessity 'cyborg writing'. The contribution of this paper therefore lies in showing how the gendered process of writing is not only limited to gendered constructions of the writer him or herself, but is also deeply embedded in the technologies with which we produce academic texts. Thus it is by understanding the gendered nature of the technological devices and processes that inform and shape our writing we can advance to a more complex understand an (academic) écriture féminine - one which will hopefully enrich the attempts of transgressing gender binaries in theorizing organizations and organizing.

\section{Consider the typewriter}

Since 1865 (in Europe) or 1868 (in America) writing has no longer consisted of those ink or pencil traces of a body, whose optical or acoustical signals were irretrievably abandoned in order that the readers, at least, might flee into the surrogate sensuality of handwriting. In order to allow for a series of sounds and sights to be stored, the old European storage technique had first of all to be mechanized. (Kittler, 1987, p. 113)

The German media-theorist Friedrich A. Kittler is arguably the finest theorist of the typewriter that the world has seen, which unfortunately is by most read as being akin to being a leading expert on lug-nuts or possibly the world's foremost thinker of light-switches. The typewriter, particularly in our digital age, is something both too much and too little. It is too complex to be celebrated in the same way fountain pens and pencils (see Rees, 2012) are, yet at the same time too functionally stunted to be viable in the age of laptops and tablets. At the same time, as Kittler shows in e.g. Gramophone, Film, Typewriter (1999), the typewriter is a highly interesting piece of technology, and one which deserves to be understood on its own, not merely as a tool wielded by man (sic). As 
Heidegger famously pointed out in his lectures on Parmenides, a typewriter is "an 'intermediate' thing, between a tool and a machine, a mechanism" (Heidegger 1992, p. 86), i.e. something not quite fixed - a fluid, searching form that changed the manner in which writing was conducted. It stands apart from the act of writing by longhand, with pen and paper, and created one of the first widely used "distancing" technologies that were directly used by authors when crafting their text(s).

It is also a technology with a distinctly gendered history. Even though it's early history is one of male inventors trying to outdo each other in inventiveness, with the users often being men of means or men interested in the newest gadgets, the commercialization of the typewriter was a process of crafting a new form of women's work. Typewriters were commonly seen as tools of dictation, and as those taking dictation were assumed to be female, the typewriter became, in a sense, a feminine tool (Davies, 1982; Strom, 1994). To type was seen as menial but light labor, and thus relegated to women, replacing the scriveners of yore. Typewriters were often decorated in a manner consistent with this, adorned with e.g. flowers or curlicues, and marketed directly to the women who producers assumed would use them.

But this gendering was not complete, nor did it wholly turn writing on a typewriter into a woman's domain. The machinery in question was still seen as a complex and finely tuned piece of engineering, and thus as falling within the purview of male engineers. Further, as the typewriter became an increasingly cheap piece of equipment, it also became the tool of choice for young writers and experimenters of text (cf. Morgan, 2010). The same typewriter might thus be seen as a symbol of women's work when placed on one of the desks in the interminable lines of the typing pool, and a sign of male literary virility when standing on the desk of a young Beat poet in his flophouse room. This should not be seen as the gendering of the typewriter being simply something borrowed from the context, but rather that in the two practices of writing referred to in the above, we see gendered practices into which the typewriter introduces an 
additional level of gender symbolics. Whether it is a man or a woman helming it, the typewriter still establishes its own logic upon the process.

In her recent work on The Work of Revision (2013), Hannah Sullivan has shown how the advent of new technologies of writing brought with it not only new economies of the same, but an altogether new manner of crafting text. Whereas poets and writers of the 18th and 19th century revised only rarely and through minor tweaks - due both to the cost of paper and the costs of printing - the advent of cheap paper, cheap printing and, perhaps most importantly the typewriter, freed writers to experiment more fully with complex revisions. Sullivan argues that where earlier poets, such as Lord Byron, considered revisions the mark of failure, modernist writers embraced the possibility of rewriting and reworking text. Technology thus not only made writing easier or faster, it changed the very nature of producing a piece of writing. Where an earlier poet might have pondered if the sonnet formed in thought might be ready to be committed to paper, a modern poet might write by way of a long manuscript carefully pared down to the bare essentials.

Through this, a technology such as the typewriter becomes something more than a tool, and gains something that we with a nod to Latour (e.g. 1996) might consider having an agency of its own. This was also always Kittler's point, that media technologies have an autonomous nature, being something more than those "extensions of man" championed by McLuhan (1964). A writer at a typewriter is thus not simply processing gendered text through a practically inert technology, but taking part in a process in which the technology becomes intimately interwoven into the process. Put somewhat differently: When we observe the writer producing text with a typewriter (or, for that matter, a laptop), from the perspective of the final output, we see a cyborg - a complex hybrid of a writing identity and gendered technologies. 


\section{Writing cyborgs}

In the most basic definition of a cyborg, this is an organism that has both organic and technological, cybernetic parts (Clynes and Kline, 1960). Cyborgs are often understood as the fusing of humans with technology, so that technology becomes intimately interwoven with the flesh of a body. The cyborg is a common character in science fiction, and contemporary medical practice (not to mention some so-called "body hackers") has made the cyborg a perfectly possible, even mundane occurrence in the world - anyone with a pacemaker is, technically, a cyborg.

The concept has however been extended far beyond this embodied definition, to include the ways in which more and more of human life is mediated by technology (Gray, 1995). A pair of glasses aren't fused with the human, but they are for many an indispensable technology, the absence of which makes one feel like less than a whole human being. Similarly, as various studies have recently shown, the modern individual is often more prone to forgo pleasures of the flesh than part with their smartphone. Increasingly, then, due to the central role technology and technological equipment play in our lives - both physical and social - we can all be understood as being, to some degree, cyborgs.

In feminist theory, the notion of the cyborg was famously taken one step further by Donna Haraway, who stated "We are all chimeras, theorized and fabricated hybrids of machine and organism; in short, we are cyborgs" (1991, p. 151). In her manifesto, she broke with the essentialism of much of earlier feminism, arguing that there was no essential, universal constitution of gender identity, and that we are all agglomerations of symbols, flesh and technologies. This obviously breaks in a very specific way with the gender binary that can slip into an écriture féminine, as no such fixity remains in the agglomerations that is the cyborg.

Haraway's criticism against the notion of feminine writing would thus hinge on this potentially being - or at least slipping into - a fixed notion of being. Such a critique, then, would contest the binary characteristic that the symbolization "feminine" bring to the category of "writing". What is interesting in Haraway's 
work on cyborgs is that technology itself is relegated to play at best a supporting role. Her interest has been to highlight the hybrid nature of gender, the problematics of gender politics and the possibility of a post-essentialist such, and the manner in which social technologies and the scientific discourse can be used to lessen and reduce the complexities of gender. In other words, Haraway is not particularly interested in typewriters.

Our contention, which takes its cue from Haraway's seminal work but which wishes to emphasize the manner in which technologies can become the nexuses that create hybridity and break with gender binaries, builds on the idea that we need to be better at discussing the often complex gender politics at play in our technologies of writing and publishing, so as not to overly romanticize either feminine or masculine writing. Instead, we wish to emphasize the cyborg nature that writing has, and that one by marginalizing technology may run the risk of essentializing the writer - and his/her gender.

Despite our use of the typewriter as an example, our argument would obviously extend to any implement through which text is produced. Whether it is the cheap ballpoint pen scribbling on purloined copying paper or writing in Google Docs on a laptop from Apple (which happens to be the case with this very sentence), the writer is always already in connection with the technology of writing, and such technologies may well have a gender politics that extends beyond the localized act of writing. Thus, the scholar attempting feminine writing may well (but not necessarily) be a woman, but the technology reached for in the act of writing may introduce different multiplicities. Where Haraway was keen to pay attention to the myriad social and scientific technologies through which gender is continuously processed, our considerably more humble aspiration is to pay attention to the manner in which all writing becomes cyborg writing through the mediating process of technology-in-use.

This is not to reject the project of écriture féminine, but rather to highlight that in a cyborg world, it is not just the gender of the writer that genders the text, but also the technology within which this text is written. What we suggest is that 
taking the cyborg metaphor into consideration - and how it per Haraway's definition breaks with gender binaries - into an (academic) écriture féminine can help safeguard against such binary constructions. Therefore, by analyzing écriture féminine as also influenced by the technological processes with which academic texts are produced, we are trying to create a parallel story-line, one that brings technology more up front and into the breach, as a tool for discussing gendered writing in general. By inserting the cyborg, we wish to call for a parallel inquiry, one that could serve to enrich the theorization around écriture féminine and possibly also serve as a critique of too simplistic readings of the same. Such critique, we hope, makes pure gender binaries more difficult to uphold. We will now turn to the context of an academic writing technology journal publishing - to discuss how this might work.

\section{The gender of the journal?}

If the partial fusing of the author with the typewriter, or pen, or laptop, or dictation software connected to a cloud computing platform, is one form of cyborg writing, it is not the only such. We want to argue that the real benefit of using the cyborg metaphor in trying to inquire into the genderedness of (academic) writing is that it allows us to ask questions about more abstract and thus more invisible technologies (something which Cixous (1997) also touched upon as she was keenly aware of what the standardization of the book format and thereby publishing a text - inevitably did to a text). One of these, a mesolevel technology if you will, is that strange mechanism we refer to as a peerreviewed scholarly journal - such as Gender, Work and Organization.

Where the implements of writing are well-known to academics as technologies, many might not consider the journals within which they try to publish as being such, despite often engaging with highly sophisticated (if not always highly functional) submission systems, as well as processing PDF proofs generated through invisible back-office machinations. A contemporary journal is an agglomeration of technologies both digital, physical and social, and one could make the argument that journals are, by and large, masculine technologies. 
The contemporary journal is a publishing outlet, which prides itself on exclusionary procedures, which operate with a strict if partially invisible hierarchy, and which establishes hard limits and linear paths for textual production and consumption. The journal takes submissions as its raw material, most of which it gleefully discards - not entirely unlike the male contribution to the act of procreation. Those textual artifacts that are allowed into the machine are judged by unseen forces, although with an editor-in-chief as a final arbiter (if we, for the moment, ignore the fact that most journals are part of the greater machinery of the capitalist corporation, leaving the CEO as the true final arbiter). Acceptance is achieved by conforming to the wishes of both faceless reviewers and an editor, with conformity to pre-established rules regarding writing being a condition for even being judged (for further discussion of the publication process see e.g. Beverungen et al., 2012; Calcedo, 2011; Harvie et al., 2012; Rhodes, 2009).

These pre-established rules vary slightly from one "machine" to the next, but often follow the following pattern: Manuscripts must be prepared in one of a limited number of formats, with the dominant format of Microsoft Word often being mandated. Manuscripts must follow a recognized pattern, with titles, abstracts, keywords, recognizable formatting and a reference list. They may, at times, contain photographs or other graphics, but this is often actively discouraged, and there is an unspoken rule that there can be only a limited number of the same in a piece of writing. All graphics must conform to being printed in gray scale (although a few journals have taken to allowing color graphics in their digital versions). More complex forms of representation are forbidden, even if they might be technically possible to accommodate.

Most importantly, all writing to be published in journals such as Gender, Work and Organization needs to accept the limitations set by the journal. For instance (quotations taken from the Author Guidelines of GWO - available at http://onlinelibrary.wiley.com/journal/10.1111/(ISSN)14680432/homepage/ForAuthors.html): 
The normal length of an article submitted should be around 7000 words and longer articles may be returned for shortening before they are reviewed. [...] The body of the manuscript should be preceded by an abstract of about 150 words and three to five keywords listed in order of importance[.] [...] Headings must be short, clearly defined and not numbered. [...] References should be in Harvard style[.]

Failure to conform will routinely result in rejection. If one manages to conform enough, and if one manages to get the textual artifact that one prepared with one's "preferred" writing implement (which, today, owing to journal submission systems, cannot be a typewriter but must be a computer, preferably one running at least some Microsoft software), the text is processed by a bewildering array of line-editors and the likes, resulting in a PDF proof that the author is allowed to comment on. At this point, all texts have a uniform look, as well as a uniform style (some even have a uniform content).

Whilst this obviously does not make it impossible to write in a personal, or indeed feminine manner, the end-result of the process is that the gender of the author - as well as the gendering of the text - is challenged and controlled by the multiplicity of technology that particularly academic writing goes through. Some might of course challenge the notion that things such as linear submission systems, strict restrictions on length and rigid formatting demands, or the double-blind(ish) review process is distinctly masculine. At the same time, texts that go through said process are standardized and in that way alienated from the experimental form that is supposedly one of the hallmarks of écriture féminine. One way to pose our argument, then, is to say that the feminine writing that is the theme of this special issue of GWO is by necessity challenged by the cyborg politics of both technologies of writing and those of the journal itself, and further that we cannot consider the gendered text without also considering the gendered technologies within which they are produced. This is not to say that technologies of representation are necessarily problematic - after all, the key texts of écriture féminine are all to some degree technologically mediated and therefore also acts of cyborg writing - but to state that inquiries into the gendered nature of writing needs as well as strives to liberate writing from the 
masculine norm needs to consider the complex relationships between the potentials of limitation and liberation in technology. To state that writing is always cyborg in nature is here not the same as claiming that such texts are by necessity limited. Rather our claim is that inquiries into technological context and the gender politics of the same can be a way to enhance the project of écriture féminine, by highlighting the limitations of our academic practices and open up for a more thorough critique of patriarchal logics of representation.

\section{Whither cyborg writing?}

A call for greater amount of attention paid to the technological mediation of writing, particularly academic writing, might to some seem nitpicking or overly nerdy. However, we would contend that it is specifically as we have "naturalized" the complex construction of contemporary academic texts that the kind of gendered frameworks where feminine writing can be marginalized exist. By not paying attention to just how constricted the system of e.g. journals are, we have created a structure in which the kind of textual engagements that Cixous, Irigaray and their peers wanted to encourage become marginalized or even impossible (see also Pullen and Rhodes, 2008) - one cannot but wonder whether the classic engagements that gave rise to the notion of écriture féminine would stand a chance in the contemporary publishing apparatus that defines organization studies as a field (a system that allows for much less freedom than the book format already criticized by Cixous (1997)).

Our call for an understanding of cyborg writing should thus be seen as a comment on the preconditions for freeing writing more generally, and as a call for allowing for a greater variety of textual production. In this sense, understanding the very limitations, which an unreflected understanding of writing and publishing technologies places upon us, will in itself be an emancipatory acknowledgement. Rather than seeing writing as purely feminine or masculine, we thus see all forms of writing as cyborg writing, and a critique of the gendered nature of writing needs to take this complicated relationship to technology into consideration. Instead of treating our laptops and our journal 
submission systems as naturally occurring phenomena we need to be able to discuss the gender politics inherent in these and the manner in which the mediation of writing affects our assumptions of gender.

As an example of how technology can both free research as well as limit it, we would like to refer to the works of one of our colleagues, namely Ann Rippin (see e.g. Rippin 2006; 2013). Her works in organization theory represent a very specific form of both representational practices and organizational critique. She works mainly in arts and crafts, with a particular predilection for quilts of corporate critique. Her research methodology thus uses quilting, a representational technology, which is often (even by her) referred to or implied as being 'feminine'. This has been for her a way to both comment on femininity and women's work and to liberate her work from the limitations of standard research practices. However, in order to publish her work she is continuously forced to re-represent her work by way of photos of both wholes and details, and to 'write up' her work. In other words, in order to publish in journals - an imperative for the contemporary academic - she needs to reduce her works into texts, processed by machinery that cannot even fathom the quilt. Thus, her liberating cyborg writing (the 'writing' of the quilt) becomes processed through the so-called objective publication process, and although we feel her work retains much of the écriture féminine she espouses, it also loses much of the same in the mechanistic process of journal publication. It is in this sense that technology both liberates her academic freedom as well as neutralizes and numbs it.

It is not without it's irony that Hélène Cixous published Le Rire de la Méduse (1975) in a journal, namely L'Arc. It was translated, revised and republished a year later in Signs: Journal of Women in Culture and Society. Looking at it on the page, few things make it look any different from any other article, although it lacks the short and clearly defined headings mandated by GWO. It also lacks a list of references, which would disqualify it from practically all journals in organization studies. In a move that seems almost too perfect it also ends with a sly nod towards our field. 
She gives that there may be life, thought, transformation. This is an "economy" that can no longer be put in economic terms. Wherever she loves, all the old concepts of management are left behind.

Be this as it may, there are things that are more difficult to leave behind. We as scholars struggle with leaving journal publication behind (just like we in this paper keep to the format of GWO in order to get our work published), and thus readily accept that our writing will always already be processed through a set of complex mechanistic moves, reduced to fit the journal issue, suitable for packaging and sale by the academic publishing industry. We as writers struggle with the limitations that technologies of writing places on us, as they constrict and control us, pushing our words into the straightest of lines and most linear of narratives. We as cyborgs sit and write - possibly even in a liberating way - and somewhere down the line someone (or something) ascribe gender to our texts. The laptop, the submission system and the content management system do not care. Haraway's attempt to let the cyborg liberate us is still a project in progress within academic writing - and might, if the contemporary system remains in place, never be fulfilled.

In the end, a special issue on feminine writing in Gender, Work and Organization needs to have an awareness regarding the fact that both the special issue as a mechanism, the journal as a machine and the cyborg texts appearing therein are affected by the various gendered technological processes we've sketched out above - and that these cyborg effects may be both stronger and more invisible than we usually think. Unless we pay attention to the technologies of both writing and publishing, as well as the manner in which these may create limiting boundaries to our academic freedom, text on emancipatory writing and écriture féminine run the risk of only telling part of the story. Through this, feminine writing without a reflectivity regarding technology might not being able to enter all the levels of critique important to understand how our texts are gendered and always already at the risk of falling back into gender binaries. A gendered critique of the author writing the text is thus not a full critique without attention 
paid to the gendered technologies within which the author produces - and even more importantly, publishes - texts.

Today the typewriter has, in some communities, made a small-scale comeback. Hipsters, both male and female, can be seen using them as charmingly retro affectations in charmingly quirky co-working spaces. Due to its fall from technological grace, the typewriter may no longer carry much of the gender politics that defined much of its history. This, however, does not hold for all technologies of writing, nor for all politics of the same. For écriture féminine to become more than just a marginal possibility in academia we need inquiries into the multiplicity of ways in which the gendered body writes, but also inquiries into the multiplicity of ways in which this writing can turn us into cyborgs, into the ways through which laptops and cloud computing and ScholarOne also make themselves heard through our texts.

\section{References}

Ashcraft, K.L., Muhr, S.L., Rennstam, J. and Sullivan, K.R. (2012): Professionalization as a branding activity: Occupational identity and the dialectic of inclusivity-exclusivity. Gender, Work \& Organization, 11,5, 467-488.

Balsamo, A. (1996) Technologies of the Gendered Body: Reading Cyborg Women. Durham: Duke University Press.

Beverungen, A., Böhm, S. and Land, C. (2012) The poverty of journal publishing. Organization, 19,6, 929-938.

Borgerson, J. and Rehn, A. (2004) General economy and productive dualisms. Gender, Work \& Organization, 11,4, 455-474. 
Bowring, M. (2004) Resistance is not futile: liberating Captain Janeway from the masculine-feminine dualism of leadership. Gender, Work \& Organization, 11,4, 381-405.

Butler J. (1990) Gender trouble. New York: Routledge.

Butler J. (1993) Bodies that matter: On the discoursive limits of sex. New York: Routledge.

Brewis, J. (2005) Signing my life away? Researching sex and organization. Organization, 12,4, 493-510.

Calcedo, M.H. (2011) The story of us: on the nexus between metaphor and story in writing scientific articles. Culture and Organization, 17,5, 403-416.

Campbell, N. (2010) Future sex: Cyborg bodies and the politics of meaning. Advertising and Society Review, 11,1, DOI: 10.1353/asr.0.0045.

Chawaf, C. (1993) Mother Love, Mother Earth. New York: Garland Publishing.

Cixous, H. (1975) Le rire de la Méduse, L'Arc, 9-54.

Cixous, H. (1976) The laugh of the Medusa. Signs: Journal of Women in Culture and Society, 1,4, 875-893.

Cixous, H. (1984) Writing the Feminine. Nebraska: The University of Nebraska Press.

Cixous, H. (1997) Rootprints: Memory and Life Writing. New York: Routledge.

Clynes, M.E. and Kline, N.S. (1960) Cyborgs and space. Astronautics, September, 29-33, 74-5. Available online at http://www.scribd.com/doc/2962194/Cyborgsand-Space-ClynesKline?autodown=pdf last accessed 25 July 2013. 
Czarniawska, B. and Gustavsson, E. (2008) The (d)evolution of the cyberwoman. Organization, 15,5, 665-83.

Davies, M. (1982) Woman's Place Is At The Typewriter. Philadelphia, PA: Temple University Press.

Fotaki, M., Metcalfe, B.D. and Harding, N. (2014) Writing materiality into management and organization studies through and with Luce Irigaray. Human Relations, Published online before print April 7.

Gray, C.H. (1995) The Cyborg Handbook. New York: Taylor \& Francis.

Gray, C.H. (2001) Cyborg Citizen: Politics in the Posthuman Age. New York: Routledge.

Grenville, B. (2002) The Uncanny: Experiments in Cyborg Culture. Vancouver: Arsenal Pulp Press.

Haraway, D. (1991) A cyborg manifesto: science, technology, and socialistfeminism in the late twentieth century. In Haraway, D. (eds.) Simians, Cyborgs and Women, pp. 149-81. New York: Routledge.

Harvie, D., Lightfoot, G., Lilley, S. and Weir, K. (2012) What are we to do with Feral Publishers. Organization, 19, 6, 905-914.

Heidegger, M. (1992), Parmenides (1942-1943). Bloomington: Indiana University Press.

Höpfl, H. (2000) The suffering mother and the miserable son: Organizing women and organizing women's writing. Gender, Work \& Organization, 7,2, 98-105. 
Höpfl, H. (2007) The codex, the codicil and the codpiece: Some thoughts on diminution and elaboration in identity formation. Gender, Work \& Organization, $14,6,619-632$.

Irigaray, L. (2002) To Speak is Never Neutral. London: Continuum.

Kittler, F. (1987). Gramophone, film, typewriter. October, 41, 101-118.

Kittler, F. (1999) Gramophone, Film, Typewriter. Stanford, CA: Stanford University Press.

Kristeva, J. (1980) Desire in Language: A Semiotic Approach to Literature and Art. New York: Columbia University Press.

Kristeva, J. (1984) Revolution in Poetic Language. New York: Columbia University Press.

Latour, B. (1996) Aramis, or the Love of Technology. Cambridge, MA: Harvard University Press.

Linstead, S. and Pullen, A. (2006) Gender as multiplicity: Desire, displacement, difference and dispersion. Human Relations, 59,9, 1287-310.

McLuhan, M. (1964) Understanding Media. London: Routledge.

Morgan, B. (2010) The Typewriter is Holy: The Complete, Uncensored History of the Beat Generation. New York: Simon \& Schuster.

Muhr, S.L. (2008) Othering diversity: A Levinasian analysis of diversity management. International Journal of Management Concepts and Philosophy, 3, 2, 176-189.

Muhr, S.L. (2011) Caught in the gendered machine: On the masculine and feminine in cyborg leadership. Gender, Work \& Organization, 18,3, 337-357. 
Muhr, S.L. and Sullivan, K.R. (2013) "None so queer as folk": Gendered expectations and transgressive bodies in leadership. Leadership, 9,3, 416-435.

Nyberg, D. (2012) Computers, Customer Service Operatives and Cyborgs: Intraactions in Call Centres. Organization Studies, 30,11, 1181-1199.

Parker, M. (1998) Judgement day: Cyborganization, humanism and postmodern ethics. Organization, 5,4, 503-518.

Parker, M. (1999) Manufacturing bodies: Flesh, organisation, cyborgs. In Hassard, J., Holliday, R. and Willmott, H. (eds.) Organising the Body, pp. 71-86. London: Sage.

Phillips, M., Pullen, A. and Rhodes, C. (2014) Writing organization as gendered practice: interrupting the libidinal economy. Organization Studies, 35,3, 313-333.

Pullen, A. (2006) Gendering the research self: Social practice and corporeal multiplicity in the writing of organizational research. Gender, Work \& Organization, 13,3, 277-298.

Pullen, A. and Rhodes, C. (2008) Dirty writing. Culture and Organization, 14,3, 241-259.

Rees, D. (2012) How To Sharpen Pencils. Brooklyn: Melville House.

Rippin, A. (2006) Refusing the therapeutic: Marion Milner and me. Culture and Organization, 12,1, 25-36.

Rippin, A. (2013) Putting the Body Shop in its place: A studio-based investigation into the new sites and sights of organization as experience. Organization Studies. $34,10,1551-1562$. 
Rhodes, C. (2009) After reflexivity: Ethics, freedom and the writing of organization studies. Organization Studies, 30,6, 653-672.

Strom, S. (1994) Beyond the Typewriter: Gender, Class, and the Origins of Modern American Office Work, 1900-1930. Chicago: University of Illinois Press.

Sharp, S. (2007) Fembot feminism: The cyborg body and feminist discourse in The Bionic Woman. Women's Studies, 36,7, 507-23.

Sullivan, H. (2013) The Work of Revision. Cambridge, MA: Harvard University Press. 